\title{
Nutrient constraints to tropical agroecosystem productivity in long-term degrading soils
}

\author{
SOLOMON NGOZE*, SUSAN RIHA*, JOHANNES LEHMANN†, LOUISVERCHOT \\ JAMES KINYANGI†, DAVID MBUGUA $₫$ and ALICE PELL $\S$ \\ *Department of Earth and Atmospheric Sciences, Cornell University, Ithaca, NY 14853, USA, †Department of Crop and Soil \\ Sciences, Cornell University, Ithaca, NY 14853, USA, $\ddagger$ World Agroforestry Centre (ICRAF), PO Box 30677, Nairobi, Kenya, \\ §Department of Animal Science, Cornell University, Ithaca, NY 14853, USA
}

\begin{abstract}
Soil degradation is one of the most serious threats to sustainable crop production in many tropical agroecosystems where extensification rather than intensification of agriculture has occurred. In the highlands of western Kenya, we investigated soil nitrogen (N) and phosphorus (P) constraints to maize productivity across a cultivation chronosequence in which land-use history ranged from recent conversion from primary forest to 100 years in continuous cropping. Nutrient treatments included a range of $N$ and $P$ fertilizer rates applied separately and in combination. Maize productivity without fertilizer was used as a proxy measure for indigenous soil fertility (ISF). Soil pools of mineral nitrogen, strongly bound $P$ and plant-available $P$ decreased by $82 \%, 31 \%$ and $36 \%$, and $P$ adsorption capacity increased by $51 \%$ after 100 years of continuous cultivation. For the long rainy season (LR), grain yield without fertilizer declined rapidly as cultivation age increased from 0 to 25 years and then gradually declined to a yield of $1.6 \mathrm{Mg} \mathrm{ha}^{-1}$, which was maintained as time under cultivation increased from 60 to 100 years. LR grain yield in the old conversions was only $24 \%$ of the average young conversion grain yield $\left(6.4 \mathrm{Mgha}^{-1}\right)$. Application of either $\mathrm{N}$ or $\mathrm{P}$ alone significantly increased grain yield in both the LR and short rainy (SR) seasons, but only application of $120 \mathrm{~kg} \mathrm{~N} \mathrm{ha}^{-1}$ on the old conversion increased yield by $>1 \mathrm{Mg} \mathrm{ha}^{-1}$. In both SR and LR, there was a greater average yield increment response to $\mathrm{N}$ and $\mathrm{P}$ when applied together (ranging from 1 to $3.8 \mathrm{Mgha}^{-1}$ for the LR), with the greatest responses on the old conversions. The benefit-cost ratio (BCR) for applying $120 \mathrm{~kg} \mathrm{~N} \mathrm{ha}^{-1}$ alone was $<1$ except on the old conversions, while BCRs were $>1$ for applying $25 \mathrm{kgP} \mathrm{ha}^{-1}$ alone at all levels of conversion for both seasons. Application of both $\mathrm{N}\left(120 \mathrm{~kg} \mathrm{~N} \mathrm{ha}^{-1}\right)$ and $\mathrm{P}$ $\left(25 \mathrm{~kg} \mathrm{Pha}^{-1}\right)$ on the old conversions resulted in the greatest BCRs. This study clearly indicates that maize productivity responses to $\mathrm{N}$ and $\mathrm{P}$ fertilizer are significantly affected by the age of cultivation and its influence on ISF, but that loss of productivity can be restored rapidly when these limiting nutrients are applied. Management strategies should consider ISF and economic factors to determine optimal $\mathbf{N}$ and $\mathrm{P}$ input requirements for achieving and sustaining profitable crop production on degraded soils.
\end{abstract}

Keywords: chronosequence, fertilizer, long-term cultivation, nitrogen, phosphorus, soil fertility, soil fertility repletion

Received 13 August 2007; revised version received 21 May 2008 and accepted 29 May 2008

Introduction

Over the past several decades in developing countries, expansion of the agricultural land base through conver-

Correspondence: Solomon Ngoze, fax + 1607255 2106, e-mail: son2@cornell.edu sion of forests, wetlands and other natural habitats has been widely recognized as having had a significant impact on the global environment (Barbier, 2007; Lal, 2007). Land continues to be brought into cultivation in many parts of Africa and South and Central America (FAO, 2005), whereas the amount of cropland area is currently decreasing in most European countries (Smith 
et al., 2005). Over the past century, approximately $40 \%$ of Africa's agricultural land has been created from forest land (Pimm et al., 2001). Tropical forest clearing for agriculture significantly alters soil biogeochemical cycles (Boyer \& Howarth, 2002; Solomon et al., 2007). After clearing and tillage, the soil plant-available nutrient pool increases as a consequence of mineralization of soil organic matter (SOM). However, high fertility is short-lived (Solomon et al., 2007) if the export of nutrients through harvest and leaching is not balanced by fertilizer input (Zingore et al., 2005; Lal, 2007). The depletion rates of specific nutrients depend on a number of factors including management, soil type and climate (Davidson \& Ackerman, 1993; Wopereis et al., 2006; Ngoze, 2008; Tittonell et al., 2008).

In sub-Saharan Africa, conversion of forest area to small-scale permanent agricultural land accounts for $60 \%$ of land-use change (FAO, 2005) and is often followed by low or no use of nutrient amendments (Sanchez et al., 1997; Sanchez, 2002; Smaling et al., 2006). Both $P$ and $N$ deficiencies are widespread in sub-Saharan African agricultural soils and are the main causes of low crop productivity, especially in smallholder agriculture (Buresh et al., 1997; Sanchez et al., 1997; Haileslassie et al., 2006). Under these conditions, crop production relies on SOM decomposition and mineral weathering as sources of plant nutrients (Donovan \& Casey, 1998; Sanchez \& Swaminathan, 2005). Although the importance of fertilizer in the tropics has been recognized, its use is low (FAO, 2003). The lack of fertilizer use is correlated with clearing of natural lands for agriculture and land degradation in Africa (Smaling et al., 2006). The reduced productivity of cultivated areas contributes to greater hunger in the region (Sanchez \& Swaminathan, 2005). Because current recommendations for fertilizer application rates are low and not site specific (FAO, 2003), adoption of these recommendations often does not resolve nutrient depletion problems (Zingore et al., 2007).

While the potential for the losses of SOM and key nutrients after land conversion to agriculture have been clearly established (Townsend et al., 2002; Lal, 2007; Solomon et al., 2007; Kinyangi, 2008), questions remain regarding the impact of the dynamics of this loss on crop productivity. Does the decline in productivity reach a quasi-equilibrium state? Is the relative response to $\mathrm{N}$ and $\mathrm{P}$ alone or in combination a function of the degree of land degradation? Can loss of productivity be restored rapidly when limiting nutrients are applied? How do costs and benefits associated with the application of the limiting nutrients vary with increasing time of continuous cultivation? For smallholder maize systems in the western highlands of Kenya, we quantify loss and restoration of productivity following forest conversion of agricultural fields that have been under continuous grain cultivation as few as 3 years to $>100$ years. Such soil chronosequences can be used to study the effect of time when long-term experiments are not feasible (Stevens \& Walker, 1970). In addition to quantifying changes in productivity over time, our goal was to understand the dynamics of declining $\mathrm{N}$ and $\mathrm{P}$ fertility, the potential for recovery of productivity through the application of fertilizers and the associated costs of the recovery process.

\section{Methods}

\section{Site description}

This study was conducted from January 2004 to August 2005 on farmers' fields in two administrative units of the highlands of western Kenya, the Nandi and Kakamega/ Vihiga districts $\left(0^{\circ} 06^{\prime} \mathrm{N}, 34^{\circ} 52^{\prime} \mathrm{E}\right)$ covering an area of approximately $40 \times 20 \mathrm{~km}^{2}$ (Fig. 1). The area of the research sites was initially part of the Kakamega/Nandi forest, the largest remnant of the Guineo-Congolean forest in Kenya (Lung \& Schaab, 2004). Because of increasing population in the region, coupled with government settlement plans or illegal encroachment of forestland by farmers, conversion of primary forest to permanent agriculture is the dominant form of land-use change occurring over the past century. Soils in this area are predominantly Ultisols developed from granite (Jaetzold \& Schmidt, 1982). The region has a subhumid climate with a mean annual rainfall of $1800 \mathrm{~mm}$, which is bimodally distributed. Long rains (LR) occur from March to August, peaking in April-May. Short rains (SR) are from September to January with a peak in October. The maize planting period starts at the onset of the rains and lasts for approximately 1 month. The mean annual temperature is $24^{\circ} \mathrm{C}$ (Jaetzold \& Schmidt, 1982). The average amounts of rainfall recorded on farm during the cropping seasons for the experiments in this study were 1287, 975 and $1086 \mathrm{~mm}$ for the $2004 \mathrm{LR}$, 2004 SR and 2005 LR, respectively. Soil pH (soil: water $=1: 2.5$ ) averaged 6.6 and 6.2 for the Nandi and Kakamega/Vihiga areas, respectively.

Farms were selected based on the estimated time when land was converted from primary forest to agriculture: 1900, 1930, 1950, 1970, 1985, 1995 and 2000 (Table 1). Farms selected were reported to have fields that had been cultivated continuously from a period of $<3$ to 104 years in $\mathrm{C}_{4}$ cereals. Before the advent of maize farming in the 1930s, either of two $C_{4}$ crops, sorghum (Sorghum bicolor L. Moench.) or finger millet (Eleusine coracana L. Gaertn.), were grown in the region. After this period, these crops were replaced by maize (Zea mays L.). The farms were selected to span the entire period of 


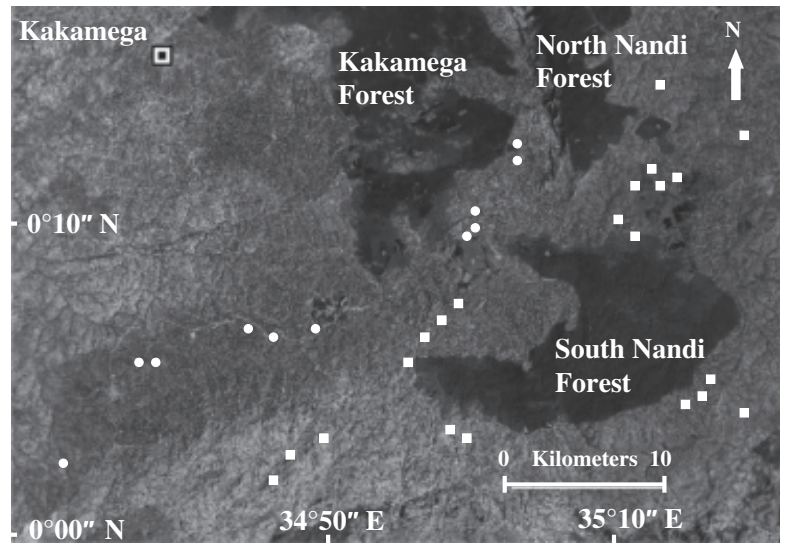

Fig. 1 Map of the experimental areas (white circles and squares represent Nandi and Kakamega/Vihiga sites, respectively) in the highlands of western Kenya.

Table 1 Time in cultivation and villages in Nandi and Kakamega districts of western Kenya where farms were located

\begin{tabular}{rll}
\hline \multirow{2}{*}{$\begin{array}{l}\text { Years of } \\
\text { cultivation }\end{array}$} & Administrative district & \\
\cline { 2 - 3 }$<3$ & Nandi & Kakamega/Vihiga \\
\hline 7 & Chebisas and Kiptuiya & Kibiri \\
17 & Kereri and Kiptuiya & Kibiri and Kamulembe* \\
32 & Kiptaruswo and Chepsui Kamulembe \\
52 & Koitabut and Chepsui & Kamulembe \\
72 & Kapkereri and Chepsui & Kamulembe \\
102 & Kapsengere & Kamulembe \\
\hline
\end{tabular}

*Villages where data was not available.

cultivation in the area while at the same time including smaller time intervals for recent land conversion, when the most rapid changes in soil properties were hypothesized to have occurred.

Important characteristics of all fields selected for establishing experimental plots, in addition to being continuously cropped to maize or other $\mathrm{C}_{4}$ cereals, included (i) similar tillage practices/cultivation intensity; (ii) no regular additions of inorganic or organic fertilizers; (iii) similar landscape positions ( $<5 \%$ slope), soil types and climatic conditions and (iv) minimal evidence of soil erosion/profile truncation. Given criteria (ii), areas around the homestead, which may preferentially receive most household organic waste and manure inputs were avoided. Information on cropping system and duration of land in cultivation was obtained through interviews with landowners, local agricultural extension and administration offices. This information was cross-checked using Landsat TEM images and data obtained from the government departments of Lands, Agriculture and Forestry. Based on farmer interviews and for the past 28 years for which records were available, maize fields were tilled using a hand hoe to a depth of $0.10-0.15 \mathrm{~m}$ in January to March for LR and in August for SR, and crop residue mainly fed to the animals and, in some cases, used as fuel.

\section{Treatments}

The study was designed to replicate a randomized complete block design (RCBD), with two blocks/sites (Nandi and Kakamega/Vihiga), seven conversion categories in each block and three farms for each conversion category was used. As only four of the seven conversion categories were successfully established in the Kakamega/Vihiga block, data was collected from a total of 33 farms. Treatments assigned to each experimental unit (field within farm) included five $\mathrm{N}$ rates of $0,30,60,90$ and $120 \mathrm{~kg} \mathrm{Nha}^{-1}$ on plots that each received $100 \mathrm{~kg} \mathrm{Pha}^{-1}$ and five $\mathrm{P}$ application rates of $0,25,50$, 75 and $100 \mathrm{~kg} \mathrm{Pha}^{-1}$ on fields treated with $120 \mathrm{~kg} \mathrm{~N} \mathrm{ha}^{-1}$ in a block design. In addition, the control treatment $(0 \mathrm{~N}$ and $0 \mathrm{P}$ ) was replicated five times on each farm to allow for an assessment of within and between field variability in productivity. The fertilizer rates used include the fertilizer rate recommended by the Kenyan Ministry of Agriculture for maize for the region, which is $25 \mathrm{~kg} \mathrm{P}$ and $60 \mathrm{~kg} \mathrm{~N}$ per hectare (MOA\&RD, 2001). Because of spatial restrictions within most farms, two sizes of plots were used: $4.5 \mathrm{~m} \times 2 \mathrm{~m}$ plots $\left(9 \mathrm{~m}^{2}\right)$ and $2.25 \mathrm{~m} \times 2 \mathrm{~m}$ $\left(4.5 \mathrm{~m}^{2}\right)$. Plots in the fields were separated by a $1 \mathrm{~m}$ path. The experimental units for all the farms were maintained for the three subsequent cropping seasons.

\section{Experiment management}

The experiment was initiated during the LR of 2004. Three treatments - (i) control $\left(\begin{array}{lllll}0 & \mathrm{P} & 0 & \mathrm{~N}\end{array}\right)$, (ii) $25 \mathrm{kgP}+120 \mathrm{~kg} \mathrm{Nha}^{-1}$ and (iii) $0 \mathrm{kgP}+120 \mathrm{~kg} \mathrm{Nha}^{-1}$ - were implemented in the first season (2004 LR). While maintaining the same design, other treatments $(\mathrm{N}$ and $\mathrm{P})$ were incorporated into the experiment in the two subsequent seasons (2004 SR and 2005 LR). For all seasons, potassium $(\mathrm{K})$ was blanket-applied in all plots at a rate of $100 \mathrm{~kg} \mathrm{Kha}^{-1}$ to ensure that all effects observed were due to $\mathrm{N}$ or $\mathrm{P}$ limitations. Fertilizers used in the treatments were urea $(45-0-0)$, triple superphosphate $(0-46-0)$ and muriate of potash $(0-0-60)$. All fertilizer materials $(\mathrm{N}, \mathrm{P}$ and $\mathrm{K})$ were broadcast by hand and incorporated into the upper $0.10-0.15 \mathrm{~m}$ soil layer at the time of planting. Thirty-three percent of $\mathrm{N}$ was applied before planting, with the remainder $(67 \%)$ side-dressed at 40 days after planting (DAP). Maize 
was hand-sown in rows at a rate of two seeds per hill spaced $0.75 \mathrm{~m}$ between rows and $0.25 \mathrm{~m}$ within rows. Maize hybrids (H614 and Phb-3253 planted in the LR and SR, respectively) differed in time to maturity and were recommended for the area and season. Seedlings were thinned 28 and 23 DAP in LR and SR, respectively, to one plant per hill, giving a cropping density of 53333 maize plants ha ${ }^{-1}$. Plots were weeded by farmers using hand hoes at 28 and 52 DAP (LR) and 23 and 55 DAP (SR). At 39 DAP (LR) and 41 DAP (SR), $2 \mathrm{~g}$ of Dipterex (Bayer Ltd (K), Nairobi, Kenya) (trichlorophon 2.5\%) was applied in each maize plant apex to control stalk borer [Buseola fusca (Fuller)].

\section{Measurements}

Grain yield was determined by hand-harvesting a subarea within each plot at physiological maturity. The outermost two rows on both sides of the plot and the first two plants at the edge of each row of each plot were not considered in the yield assessment. Maize grain was oven-dried at $75^{\circ} \mathrm{C}$ to constant weight, weighed and ground for nutrient analysis. Grain yield is expressed on an oven dry mass basis. In cases where cobs were missing from the subplot (removed by people or by baboons), the average weight of the grain per harvested cob was multiplied by the expected plant density at harvest to obtain an estimate of yield. Out of a total of 330 treatments (10 treatments per farm), six had missing cobs. In all six cases, $<35 \%$ of the cobs were missing.

Nitrogen concentration of grain samples was determined by dry combustion after fine grinding with a Cyclotec Sample Mill Tecator (model 1093; American Instrument Exchange Inc., Haverhill, MA, USA). Samples were analyzed with a Europa ANCA-GSL CN analyser (PDZ Europa Ltd, Sandbach, UK) following combustion at $1000^{\circ} \mathrm{C}$. Phosphorus concentration of finely ground oven-dried grain samples were measured using a Spectro-CCD (charge coupled device) ICP-AES unit (Spectro CIROS, Kleve, Germany) following a series of digestions with concentrated $\mathrm{HNO}_{3}$ and $\mathrm{H}_{2} \mathrm{O}_{2}$ at three temperatures: $120^{\circ} \mathrm{C}$ for $4 \mathrm{~h}, 130^{\circ} \mathrm{C}$ for $2 \mathrm{~h}$ and, finally, $145^{\circ} \mathrm{C}$ until a white colored residue was obtained (Oliva et al., 2003).

\section{Soil analysis}

Soil samples for $\mathrm{N}$ and $\mathrm{P}$ characterization were collected in all plots from the top $0.10 \mathrm{~m}$ of the profile using an auger $(0.07 \mathrm{~m}$ diameter) in January 2004 (before fertilizer application), bulked and thoroughly mixed to a representative composite sample per farm. Soils were sampled to $0.1 \mathrm{~m}$ because the plough depth in this area generally ranged from 0.10 to $0.15 \mathrm{~m}$. Cores were taken from the experimental units to determine soil bulk density, which was later used to convert $\mathrm{N}$ and $\mathrm{P}$ values from $\mathrm{mg} \mathrm{kg}^{-1}$ to $\mathrm{kg} \mathrm{ha}^{-1}$.

Soil samples were analyzed for mineral $\mathrm{N}\left(\mathrm{NH}_{4}-\mathrm{N}\right.$ and $\mathrm{NO}_{3}-\mathrm{N}$ ), with two subsamples for each sample, after extraction with $2 \mathrm{M} \mathrm{KCl}$. The resulting extract was analyzed for $\mathrm{NH}_{4}-\mathrm{N}$ and $\mathrm{NO}_{3}-\mathrm{N}$ colorimetrically following the procedure of Anderson \& Ingram (1993) and Dorich \& Nelson (1984).

Phosphorus fractions in the soil samples were analyzed using a sequential extraction procedure following the modified method of Hedley et al. (1982), as described in Tiessen \& Moir (1993), with $\mathrm{HCO}_{3}$-saturated resin strips (BDH \#55164, $9 \mathrm{~mm}$ ). This was followed by extraction with $0.5 \mathrm{M} \mathrm{NaHCO} 3$ (referred to as bicarbonate-P), $0.1 \mathrm{M} \mathrm{NaOH}$, (these first three steps each with an extracting time of $16 \mathrm{~h}$ ) and concentrated hot $\mathrm{HCl}$ at $80^{\circ} \mathrm{C}$ for $10 \mathrm{~min}$. The dilute $\mathrm{HCl}$ extraction was omitted, because Ca-phosphates are either absent or present in very small quantities in this region (Friesen et al., 1997; Nziguheba et al., 1998). After each extraction, the samples were centrifuged at $25000 \times g$ for $10 \mathrm{~min}$ before filtering the solutions of the bicarbonate and the $\mathrm{NaOH}$ extracts. Phosphorus concentrations in all extracts were measured after neutralization by the Murphy \& Riley (1962) method. This method was used directly for the $P$ recovered from the resin strips and for inorganic $P\left(P_{i}\right)$ determination in the $\mathrm{HCl}$ extracts. Organic matter was first precipitated by acidification in the bicarbonate and the $\mathrm{NaOH}$ extracts before $\mathrm{P}_{\mathrm{i}}$ determination (Tiessen \& Moir, 1993). Total $\mathrm{P}$ in the bicarbonate, the $\mathrm{NaOH}$ and the $\mathrm{HCl}$ extracts was measured after digestion of extracts with potassium persulfate (Bowman, 1989). Organic $\mathrm{P}$ was calculated as the difference between total $\mathrm{P}$ and $\mathrm{P}_{\mathrm{i}}$ in the bicarbonate, $\mathrm{NaOH}$ and hot $\mathrm{HCl}$ extracts.

Phosphorus sorption capacity was determined using the method of Fox \& Kamprath (1970). Three grams of soil were mixed with $30 \mathrm{~mL}$ of $0.01 \mathrm{M} \mathrm{CaCl}_{2}$ with eight $\mathrm{P}$ concentrations $(0,100,200,300,400,500$ and $600 \mathrm{mg} \mathrm{P} \mathrm{kg}^{-1}$ ) plus two drops of toluene (to stop microbial activity) in $50 \mathrm{~mL}$ plastic centrifuge tube. These units were incubated at $25^{\circ} \mathrm{C}$ for 6 days with two $30 \mathrm{~min}$ shakings at $150 \mathrm{rpm}$ every day. At the end of the incubation, the samples were filtered and analyzed colorimetrically for P (Murphy \& Riley, 1962). Phosphorus adsorbed was calculated as the difference between the P added and the final P in the solution. The data from the adsorption isotherms were analyzed using the Langmuir equation $[q=k b c /(1+k c)]$ to estimate the adsorption affinity $k\left(\mathrm{~L} \mathrm{mg}^{-1}\right)$ and adsorption maximum $b\left(\mathrm{mg} \mathrm{P} \mathrm{kg}^{-1}\right)$, where $q$ is the amount of $\mathrm{P}$ adsorbed $\left(\mathrm{mg} \mathrm{P} \mathrm{kg}^{-1}\right)$ and $c$ is the solution concentration $\left(\mathrm{mg} \mathrm{PL}^{-1}\right)$. The equilibrium solution level of $0.2 \mathrm{mg} \mathrm{PL}^{-1}$ has traditionally been used as a point of 
reference because it relates to a threshold above which there is little crop response to $\mathrm{P}$ for many soils (Kamprath \& Watson, 1980).

\section{Statistical analysis}

After preliminary analyses, grain yield for LR and SR were analyzed separately and as there were no statistical differences between the LR of 2004 and 2005, the grain yield for the two seasons were pooled. In all cases, grain yield data were analyzed as a RCBD with two sites, up to seven intervals of land conversion, three replications (farms) and $\mathrm{N}$ and $\mathrm{P}$ fertilizer rates. Control (no input) plots and farms were expressed as random variables in a mixed effects model used to evaluate between and within farm variability. All statistical comparisons were made at $\alpha=0.05$ probability level unless otherwise stated. If the analysis of variance indicated a significant $F$-value for $\mathrm{N}$ or $\mathrm{P}$ treatments, a linear or quadratic function was fitted to the $\mathrm{N}$ and $\mathrm{P}$ response data.

Control grain yields as a function of time in cultivation were fitted with exponential models. To facilitate the analysis and presentation of the fertilizer response data, years of conversion from forest were grouped into three categories: young (2000), medium (1985) and old (1970, 1950, 1930 and 1900). More years of conversion were included in the old category because there was only a small decline in control yields on sites cultivated for > 35 years. In the case of the $\mathrm{N}$ and $\mathrm{P}$ fertilizer treatments, there was insufficient data from 1995 to include in the analysis.

The apparent fertilizer recoveries for both nitrogen (ANR) and phosphorus (APR) were calculated as N or P uptake (fertilized plot) minus $\mathrm{N}$ or $\mathrm{P}$ uptake (control plot) and then divided by total $\mathrm{N}$ or $\mathrm{P}$ fertilizer rate. Grain yield increment above control treatment (without fertilizer application) was used to assess the effect of the experiment's highest and lowest $P$ rates (25 and $\left.100 \mathrm{P} \mathrm{kg} \mathrm{ha}^{-1}\right)$, and highest $\mathrm{N}$ rate $\left(120 \mathrm{~N} \mathrm{~kg} \mathrm{ha}^{-1}\right)$.
We used benefit-cost ratios (BCR), the present worth of the benefit stream divided by present worth of the cost stream, to determine the economic value of fertilization. Benefit-cost ratio is a discounted measure of project worth. Each combination of fertilizer applied was taken as a 'project'. In this case, BCR was calculated on an area basis with the benefit stream defined as returns due to increase in yield above control and the cost stream defined as the cost of fertilizer. Price of grain was assumed to be constant across the chronosequence. Based on a survey carried out in 2005 (Mutuo et al., 2006) a farm gate price of 20 Kenya shillings (76 Kenya shillings $=1$ USD) per kg of dry maize grain was used. The cost of fertilizer was calculated assuming that $50 \mathrm{~kg}$ of triple superphosphate and $50 \mathrm{~kg}$ of urea cost 1950 and 2000 Kenyan shillings, respectively. The cost of N and P per $\mathrm{kg}$ was Kenya shillings 205.3 and 88.9, respectively. If the BCR ratio is greater than unity (1), there is a potential positive return on investment. We also assessed the net benefit as the value of the grain above control minus the cost of the fertilizer applied.

\section{Results}

\section{Initial soil characteristics}

Tables 2 and 3 present soil $\mathrm{N}$ and the $\mathrm{P}$ pools and $\mathrm{P}$ adsorption characteristics before fertilizer was applied. Preliminary analyses indicated that the measured $\mathrm{N}$ and $\mathrm{P}$ levels did not vary by block, so data from both blocks were pooled for subsequent analyses. Soil mineral nitrogen, strongly bound $\mathrm{P}$ and plant-available $\mathrm{P}$ decreased with the increasing lengths of time that land was in cultivation (Table 2). The organic $\mathrm{P}$ and inorganic $P$ pools were lower for old conversions compared with medium and young conversions. Amount of $\mathrm{P}$ adsorbed at an equilibrium solution of $0.2 \mathrm{mg} \mathrm{PL}^{-1}$ increased with the age of cultivation, as did adsorption maximum (Table 3).

Table 2 Soil phosphorus (P) pools and mineralized nitrogen $(\mathrm{N})$ at different ages of conversion before fertilizer application

\begin{tabular}{|c|c|c|c|c|c|c|c|c|}
\hline \multirow[b]{3}{*}{ Conversion } & \multirow{2}{*}{$\frac{\text { Resin }}{P_{i}}$} & \multicolumn{2}{|c|}{$\mathrm{NaHCO}_{3}$} & \multicolumn{2}{|c|}{$\mathrm{NaOH}$} & \multirow[b]{2}{*}{$\mathrm{P}_{\mathrm{A}}$} & \multirow[b]{2}{*}{ Sum $P$} & \multirow{2}{*}{$\frac{\text { KCL extracted }}{\text { Nitrogen }}$} \\
\hline & & $P_{i}$ & $\mathrm{P}_{\mathrm{o}}$ & $P_{i}$ & $P_{o}$ & & & \\
\hline & $\mathrm{kgha}^{-1}$ & & & & & & & \\
\hline Young & $20 \mathrm{a}$ & $14 \mathrm{a}$ & $41 \mathrm{a}$ & $85 \mathrm{a}$ & $242 \mathrm{a}$ & $75 \mathrm{a}$ & 402 a & $74 \mathrm{a}$ \\
\hline Medium & $16 a$ & $10 \mathrm{~b}$ & $31 \mathrm{~b}$ & $71 \mathrm{a}$ & $182 \mathrm{~b}$ & $57 \mathrm{a}$ & $311 \mathrm{~b}$ & $32 \mathrm{~b}$ \\
\hline Old & $14 \mathrm{~b}$ & $12 \mathrm{~b}$ & $22 \mathrm{c}$ & $50 \mathrm{~b}$ & $175 \mathrm{~b}$ & $48 \mathrm{~b}$ & $273 c$ & $13 \mathrm{c}$ \\
\hline
\end{tabular}

Conversion is the age of conversion from primary forest to agriculture. $\mathrm{P}_{\mathrm{i}}$, inorganic $\mathrm{P} ; \mathrm{P}_{\mathrm{o}}$, organic $\mathrm{P} ; \mathrm{P}_{\mathrm{A}}$, plant available $\mathrm{P}$ (Resin $\mathrm{P}_{\mathrm{i}}+\mathrm{NaHCO}_{3} \mathrm{P}_{\mathrm{i}}+\mathrm{NaHCO}_{3} \mathrm{P}_{\mathrm{o}}$ ). Sum $\mathrm{P}=$ Resin $+\mathrm{NaHCO}_{3}+\mathrm{NaOH}$. Nitrogen is mineralized N $\left(\mathrm{NH}_{4}-\mathrm{N}+\mathrm{NO}_{3}-\mathrm{N}\right)$. Different letters within the column indicate significant differences between the means of the conversions at $P<0.05$. 
Table 3 P adsorption characteristics obtained using Langmuir equation and absorption at an equilibrium solution of $0.2 \mathrm{mg} \mathrm{P} \mathrm{L}^{-1}$

\begin{tabular}{|c|c|c|c|}
\hline Conversion & $\begin{array}{l}\text { Bonding } \\
\text { energy, } k \\
\left(\mathrm{~L} \mathrm{mg}^{-1}\right)\end{array}$ & $\begin{array}{l}\text { Adsorption } \\
\max , b \\
\left(\mathrm{mg} \mathrm{P} \mathrm{kg}^{-1}\right)\end{array}$ & $\begin{array}{l}\mathrm{P} \text { adsorbed at } \\
0.2 \mathrm{mg} \mathrm{P} \mathrm{L}^{-1} \\
\left(\mathrm{mg} \mathrm{P} \mathrm{kg}^{-1}\right)\end{array}$ \\
\hline Young & 1.8 & 514 & 102 \\
\hline Medium & 3.1 & 527 & 185 \\
\hline Old & 3.5 & 580 & 250 \\
\hline
\end{tabular}

\section{Effect of time under cultivation on productivity}

Within block, within farms and within plot (seasonal) variances in control grain yield were $20 \%, 15 \%$ and $65 \%$, respectively, of the total variance. As a function of years under cultivation, declines in LR and SR season maize grain yield without $\mathrm{N}$ or $\mathrm{P}$ fertilizer were described by three- and two-parameter exponential decay models, respectively (Fig. 2). The SR season had a lower yield potential and rate of grain yield decline without fertilizer than the LR season (the interaction of season by years was significant at $P<0.001)$. In the LR season, grain yield (6.9 Mg ha ${ }^{-1}$ for young conversion) declined rapidly in the first 25 years of cultivation and then approached a minimum yield of $1.6 \mathrm{Mg} \mathrm{ha}^{-1}$ more gradually. Half of the young conversion grain yield potential was lost in the first 24 years. The grain yield decreased exponentially from young conversions to about $23 \%$ of the original yield following long-term cultivation. On land with 35 or more years in cultivation, maize grain yields in the LR and SR seasons were similar.

\section{Effect of $N$ fertilization on productivity}

The application of $\mathrm{N}$ significantly increased grain yield in both the LR and SR seasons (Table 4). Grain yield in the LR varied from 1.2 to $7.3 \mathrm{Mg} \mathrm{ha}^{-1}$ for a range of $\mathrm{N}$ fertilizer application rates at a high $\mathrm{P}$ fertilization rate $\left(100 \mathrm{~kg} \mathrm{P} \mathrm{ha}^{-1}\right)$. In the LR season, grain yield response to $\mathrm{N}$ fertilization rates could be described by either a linear $(P<0.001)$ or quadratic $(P=0.015)$ model depending on the age of conversion (Fig. 3, Table 5). Based on the response models, grain yields with $100 \mathrm{~kg} \mathrm{P} \mathrm{ha}^{-1}$ and no $\mathrm{N}\left(0 \mathrm{~kg} \mathrm{Nha}^{-1}\right)$ were $5.1,3.6$ and $1.8 \mathrm{Mg} \mathrm{ha}^{-1}$ for the young, medium and old conversions, respectively (Table 5). Medium and young conversion grain-yield responses to $\mathrm{N}$ were similar with $\mathrm{N}$ application rates $>60 \mathrm{~kg} \mathrm{Nha}^{-1}$ (Fig. 3). It is likely that $\mathrm{N}$ was still limiting grain yield on the older conversions even at $\mathrm{N}$ fertilizer application rates as high as $120 \mathrm{~kg} \mathrm{Nha}^{-1}$. The young conversions had very low $(<30 \%)$ ANR efficiencies at all $\mathrm{N}$ fertilizer rates $>30 \mathrm{kgNha}^{-1}$.

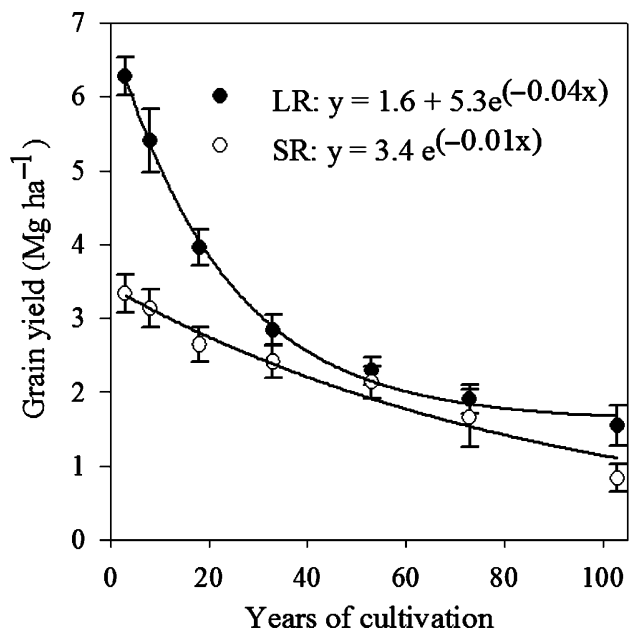

Fig. 2 Effect of no $\mathrm{N}$ or $\mathrm{P}$ application (absolute control treatment) on maize yields during the long (LR) and short (SR) rainy seasons as a function of years under cultivation. The error bars are standard error of the mean.

Table 4 Analysis of variance for the effect of years of cultivation (year) and site across the chronosequence on long (LR) and short rainy (SR) season grain yield

\begin{tabular}{|c|c|c|c|c|}
\hline \multirow[b]{3}{*}{ Treatment } & \multirow[b]{3}{*}{ Source of variation } & \multirow[b]{3}{*}{$\mathrm{df}$} & \multicolumn{2}{|l|}{ Season } \\
\hline & & & LR & SR \\
\hline & & & Probabilit & \\
\hline \multirow[t]{7}{*}{$\mathrm{N}$} & Year & 5 & $<0.001$ & 0.103 \\
\hline & $\mathrm{N}$ & 4 & $<0.001$ & $<0.001$ \\
\hline & Block (Site) & 1 & 0.099 & ns \\
\hline & Year $\times \mathrm{N}$ & 20 & ns & 0.100 \\
\hline & Year $\times$ Site & 7 & ns & 0.126 \\
\hline & Site $\times N$ & 4 & ns & ns \\
\hline & Year $\times$ Site $\times N$ & 25 & ns & 0.051 \\
\hline \multirow[t]{7}{*}{ P } & Year & 4 & $<0.001$ & ns \\
\hline & $\mathrm{P}$ & 4 & $<0.001$ & $<0.001$ \\
\hline & Block (site) & 1 & ns & ns \\
\hline & Year $\times \mathrm{P}$ & 15 & 0.163 & ns \\
\hline & Year $\times$ Site & 2 & ns & ns \\
\hline & Site $\times \mathrm{P}$ & 4 & ns & ns \\
\hline & Year $\times$ Site $\times P$ & 7 & ns & ns \\
\hline
\end{tabular}

Year, years of cultivation; $\mathrm{N}, \mathrm{N}$ fertilizer rate; $\mathrm{P}, \mathrm{P}$ fertilizer rate; ns, not significant.

For the medium and old conversions, ANR was greater and decreased with increasing rate of $\mathrm{N}$ application (Fig. 3).

Grain yield responded linearly to increasing $\mathrm{N}$ rate in the SR season (Fig. 3). This response did not vary significantly with conversion age. Average grain yield ranged from 2.7 to $4.6 \mathrm{Mg} \mathrm{ha}^{-1}$ depending on $\mathrm{N}$ fertili- 

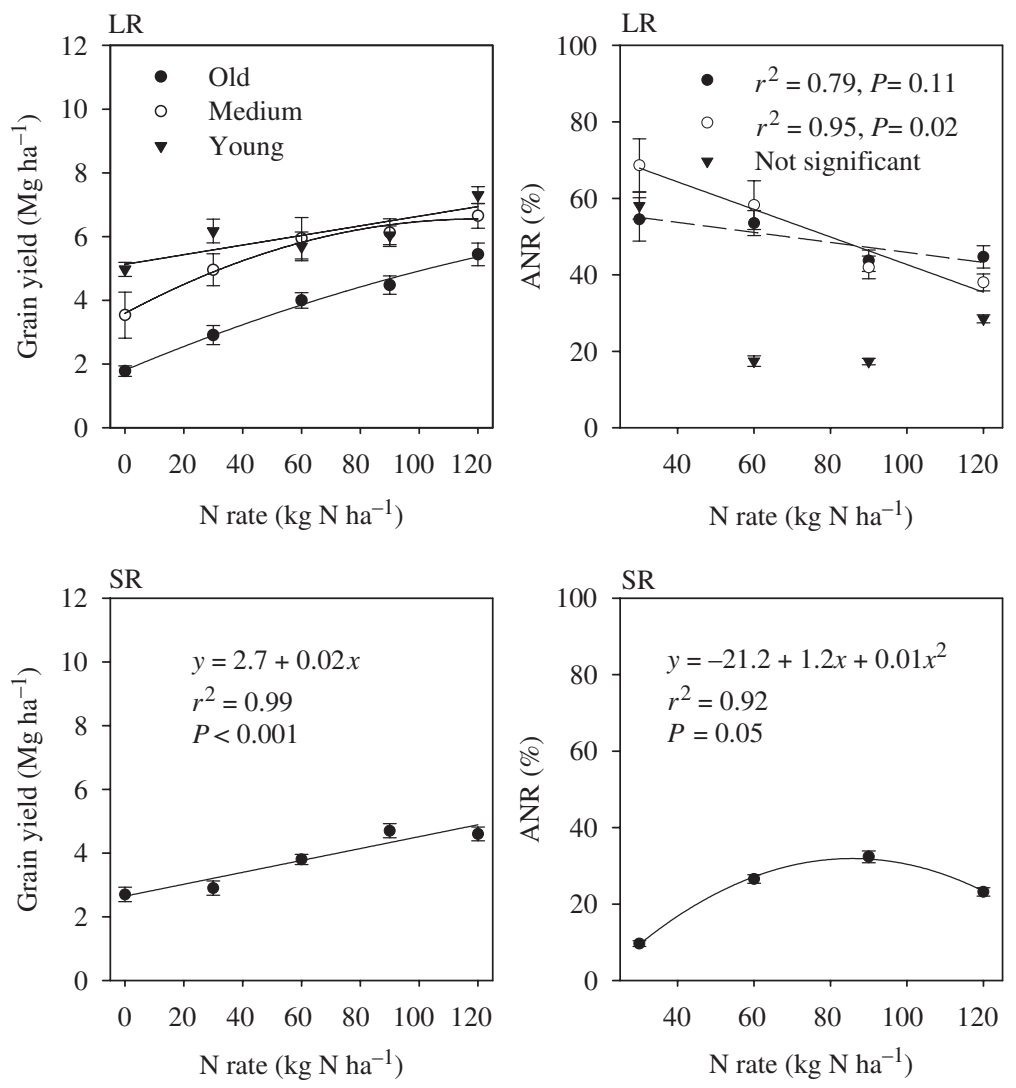

Fig. 3 Effect of increasing $\mathrm{N}$ rate on the long (LR) and short (SR) rainy seasons maize grain yield and apparent $\mathrm{N}$ recovery efficiency $(\mathrm{ANR}) . \mathrm{ANR}=[$ (treatment grain $\mathrm{N}-$ control grain $\mathrm{N}) /($ fertilizer $\mathrm{N}$ applied $)] \times 100$. All $\mathrm{N}$ treatments received $100 \mathrm{P}$ and $100 \mathrm{~kg} \mathrm{Kha}{ }^{-1}$. The error bars are standard error of the mean. Rate equations for LR grain yields are in Table 5.

Table 5 Rate equations, $r^{2}$ and $P$-values associated with yield responses to nitrogen and phosphorus fertilizer application during the long rainy season for the three categories of conversions

\begin{tabular}{lllll}
\hline \multirow{2}{*}{ Response } & $\begin{array}{l}\text { Conversion } \\
\text { category }\end{array}$ & Equation & $r^{2}$ & $P$ \\
\hline \multirow{2}{*}{ Nitrogen } & Young & $y=5.13+0.015 x$ & 0.71 & 0.072 \\
& Medium & $\begin{array}{l}y=3.59+0.050 \\
x-0.0002 x^{2}\end{array}$ & 0.99 & 0.016 \\
& Old & $y=1.81+0.039$ & 0.99 & 0.008 \\
& & $x-0.0001 x^{2}$ & & \\
Phosphorus & Young & $y=6.64+0.007 x$ & 0.85 & 0.026 \\
& Medium & $y=4.29+0.024 x$ & 0.94 & 0.006 \\
& Old & $y=3.19+0.024 x$ & 0.90 & 0.013 \\
\hline
\end{tabular}

$y$ is the grain yield in $\mathrm{Mgha}^{-1}$ and $x$ is the applied fertilizer $\mathrm{kg} \mathrm{P}$ or $\mathrm{kg} \mathrm{N}$ applied ha ${ }^{-1}$.

zer rate (Fig. 3). There did not appear to be a response to $\mathrm{N}$ above $90 \mathrm{~kg} \mathrm{~N} \mathrm{ha}^{-1}$. The ANR efficiency in the SR was generally low and did not significantly decrease with increasing $\mathrm{N}$ application rate (Fig. 3).

\section{Effect of $P$ fertilization on productivity}

Grain yield was significantly affected by years in cultivation and $P$ rates in the LR season, but only $P$ rate was significant in the SR (Table 4). The same categories of conversion (young, medium and old) used for $\mathrm{N}$ response were used to analyze response to P. All three categories of conversions (young, medium and old) responded positively to the applied $\mathrm{P}$ rates at the highest rate of applied $\mathrm{N}\left(120 \mathrm{kgNha}^{-1}\right)$ (Fig. 4). A linear model could be used to describe LR grain yield responses to applied $\mathrm{P}$ in all three conversion categories (Table 5). From these regressions, predicted grain yields in the LR when $120 \mathrm{kgNha}^{-1}$ was applied but with no added $\mathrm{P}$ were $6.6,4.3$ and $3.2 \mathrm{Mgha}^{-1}$ for the young, medium and old conversions, respectively (Table 5). The young conversion category had a lower rate of increase in grain yield in response to added $P$ than the medium and old conversions (Table 5). At the highest rate of applied P $\left(100 \mathrm{~kg} \mathrm{Pha}^{-1}\right)$, the medium and young conversion grain yields were similar. The APR efficiency decreased similarly with increasing 

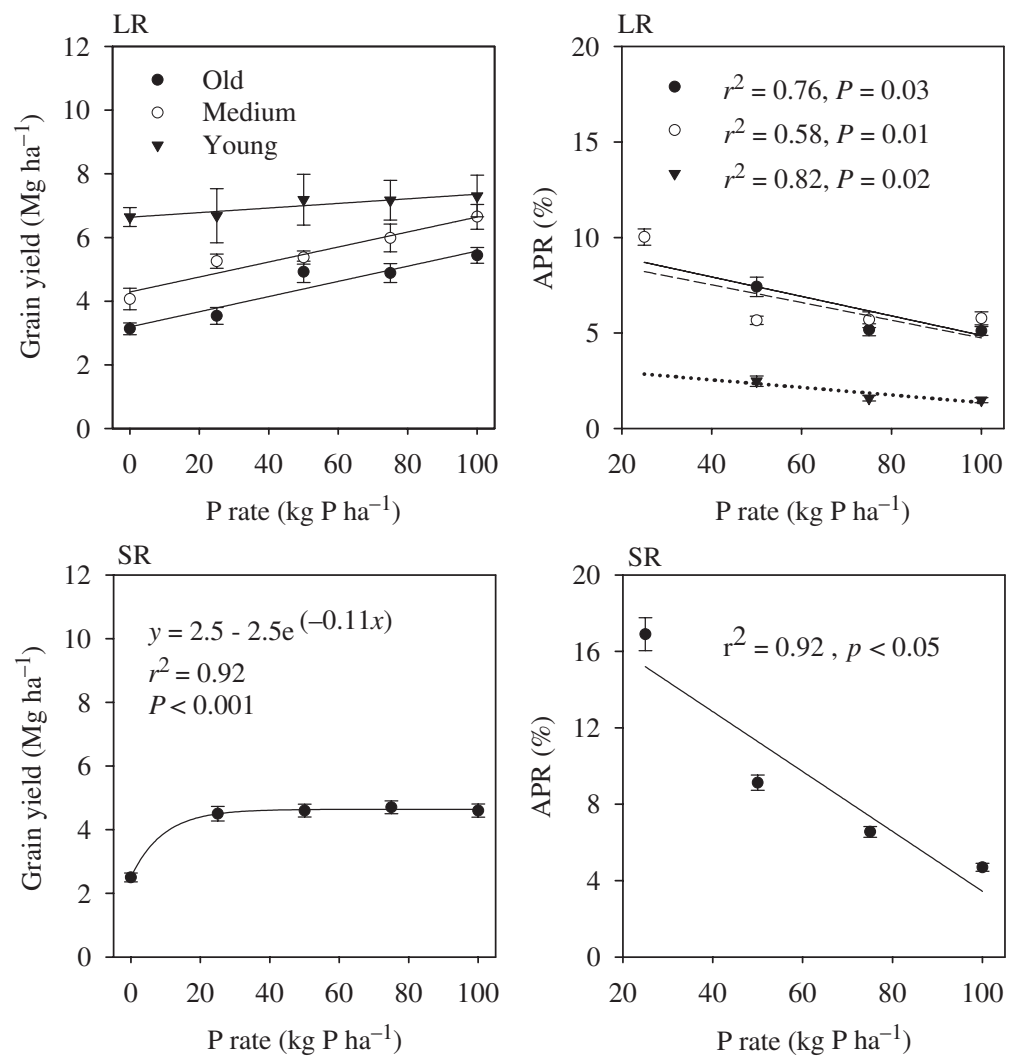

Fig. 4 Effect of increasing $P$ rate on the long (LR) and short (SR) rainy seasons maize grain yield and apparent $\mathrm{P}$ recovery efficiency $(\mathrm{APR}) . \mathrm{APR}=[($ treatment grain $\mathrm{P}-$ control grain $\mathrm{P}) /($ fertilizer $\mathrm{P}$ applied $)] \times 100$. All $\mathrm{P}$ treatments received $120 \mathrm{~N}$ and $100 \mathrm{~kg} \mathrm{~K} \mathrm{ha}{ }^{-1}$. The error bars are standard error of the mean. Rate equations for LR grain yields are in Table 5.

$\mathrm{P}$ rates in the medium and old conversions. The young conversion had lower APRs and lower rate of APR decline than the old and medium conversions.

In the SR, the maximum grain yield under the highest level of $\mathrm{N}$ fertilization $\left(120 \mathrm{~kg} \mathrm{~N} \mathrm{ha}^{-1}\right)$ and $\mathrm{P}$ fertilization $\left(100 \mathrm{~kg} \mathrm{Pha}^{-1}\right.$ ) was $4.5 \mathrm{Mg} \mathrm{ha}^{-1}$ (Fig. 4). There was no significant effect of years in cultivation on $\mathrm{P}$ response and no yield increase from applying $>25 \mathrm{~kg} \mathrm{Pha}^{-1}$ (Fig. 4). The SR season APR declined with increasing $P$ rates (Fig. 4).

\section{Effect of $N$ and $P$ fertilization on productivity}

Figure 5 summarizes yield increases above the control (no $\mathrm{N}$ or $\mathrm{P}$ fertilizer applied) as a function of years of cultivation for both the LR and SR. In the SR, application of either $\mathrm{N}\left(120 \mathrm{kgNha}^{-1}\right)$ or $\mathrm{P}\left(25 \mathrm{kgPha}^{-1}\right)$ alone on sites that were converted $<50$ years ago resulted in similar, small $\left(<0.5 \mathrm{Mgha}^{-1}\right)$ increases in grain (Fig. 5). The grain yield increase was only $>1 \mathrm{Mgha}^{-1}$ for the old conversions with an $\mathrm{N}$ application rate of $120 \mathrm{~kg} \mathrm{Nha}^{-1}$. However, the application of just $25 \mathrm{kgPha}^{-1}$ with $120 \mathrm{kgNha}^{-1}$ resulted in yield increases of up to $2.7 \mathrm{Mg} \mathrm{ha}^{-1}$ on the old conversions in the SR (Fig. 5).

During the LR, there was a slightly greater response in grain yield to $\mathrm{N}$ and $\mathrm{P}$ applied separately as found for the SR (Fig. 5). As with the SR, in the LR there was a much greater yield increment response to $\mathrm{N}$ and $\mathrm{P}$ when both nutrients were applied (Fig. 5), but in this case the yield response was even greater with an application of $100 \mathrm{~kg} \mathrm{Pha}^{-1}$ compared with $25 \mathrm{~kg} \mathrm{Pha}^{-1}$. Again, there was an indication that the old conversions would have responded to higher rates of $\mathrm{N}$ application, with yield increments even $>4 \mathrm{Mg} \mathrm{ha}^{-1}$.

\section{$B C R$ and net benefit of $N$ and $P$ fertilization}

Application of $120 \mathrm{~kg} \mathrm{Nha}^{-1}$ fertilizer when no $\mathrm{P}$ was applied resulted in a $\mathrm{BCR}<1$ except for the old conversion, which was about 1 (Table 6). Application of $25 \mathrm{~kg} \mathrm{Pha}{ }^{-1}$ when no $\mathrm{N}$ was applied resulted in 

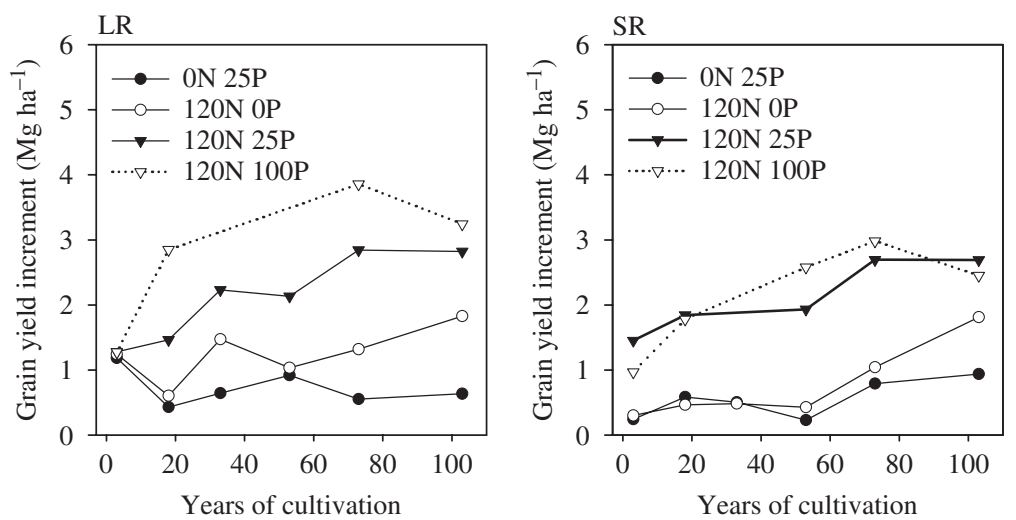

Fig. 5 Grain yield increment above absolute control on the chronosequence for both long (LR) and short (SR) rainy seasons. Yield increase above control due to addition of $\mathrm{N}\left(120 \mathrm{~kg} \mathrm{Nha}^{-1}\right)$ and $\mathrm{P}\left(25\right.$ or $\left.100 \mathrm{kgPha}^{-1}\right), Y_{\mathrm{i}}=\left(Y_{\mathrm{Nor}} \mathrm{P}-Y_{\mathrm{ac}}\right)$, where $\mathrm{i}$ is the yield increment. $Y_{\mathrm{N} \text { or P }}$ is the yield $\left(\mathrm{Mg} \mathrm{ha}^{-1}\right)$ due to either application of $\mathrm{N}\left(120 \mathrm{~kg} \mathrm{Nha}^{-1}\right)$ or P $\left(25\right.$ or $\left.100 \mathrm{~kg} \mathrm{ha}^{-1}\right)$ and $Y_{\mathrm{ac}}$ is the control yield.

Table 6 Net benefit (per ha) and benefit to cost ratio of different nitrogen $(\mathrm{N})$ and phosphorus $(\mathrm{P})$ fertilizer rates

\begin{tabular}{|c|c|c|c|c|c|c|c|c|}
\hline \multirow[b]{3}{*}{ LR } & $0 \mathrm{~N}$ & $120 \mathrm{~N}$ & $120 \mathrm{~N}$ & $120 \mathrm{~N}$ & $0 \mathrm{~N}$ & $120 \mathrm{~N}$ & $120 \mathrm{~N}$ & $120 \mathrm{~N}$ \\
\hline & $25 \mathrm{P}$ & $0 \mathrm{P}$ & & & & & & \\
\hline & \multicolumn{4}{|c|}{ Net benefit Ksh ha ${ }^{-1}$} & \multicolumn{4}{|l|}{ BCR } \\
\hline Young & 8571 & -6345 & 9828 & -5675 & 2.0 & 0.5 & 1.6 & 0.8 \\
\hline Medium & 6837 & -3289 & 27555 & 25802 & 3.0 & 0.7 & 2.8 & 1.8 \\
\hline Old & 7578 & 5379 & 40662 & 39812 & 2.0 & 1.2 & 3.6 & 2.3 \\
\hline \multicolumn{9}{|l|}{ SR } \\
\hline Young & -283 & -25177 & 13246 & -11803 & 0.9 & 0.2 & 1.8 & 0.3 \\
\hline Medium & 6554 & -10317 & 21999 & 4400 & 1.7 & 0.4 & 2.3 & 1.3 \\
\hline Old & 9766 & 5044 & 38011 & 17816 & 3.5 & 1.2 & 3.4 & 2.1 \\
\hline
\end{tabular}

Net benefit is calculated as returns due to increase in yield above control minus the cost of fertilizer on a per hectare basis; BCR is the benefit-cost ratio calculated as returns due to increase in yield above control as a ratio of the cost of fertilizer; 76 Kenya shillings $(\mathrm{Ksh})=1 \mathrm{USD}$

BCRs $>1$ while $\mathrm{N}$ applied alone at $120 \mathrm{~N} \mathrm{~kg} \mathrm{ha}^{-1}$ only resulted in BCRs slightly $>1$ on the old conversions. However, application of both $\mathrm{N}\left(120 \mathrm{~kg} \mathrm{ha}^{-1}\right)$ and $\mathrm{P}$ $\left(25 \mathrm{~kg} \mathrm{ha}^{-1}\right)$ resulted in the greatest BCRs on the old conversions in the LR. Estimated average net benefits of fertilizer application were highest for $N\left(120 \mathrm{~kg} \mathrm{ha}^{-1}\right)$ and $\mathrm{P}\left(25 \mathrm{~kg} \mathrm{ha}^{-1}\right)$ when applied together for all the conversions and lowest with $\mathrm{N}\left(120 \mathrm{~kg} \mathrm{ha}^{-1}\right)$ alone.

\section{Discussion}

\section{Effect of cultivation on indigenous soil fertility (ISF)}

The yield decline patterns for the two seasons were distinctly different on conversions of $<35$ years (Fig. 2). These differences could be attributed to the different production potentials of the two seasons and consequently of the maize varieties recommended for planting and used in this study. Earlier maturing vari- eties are recommended for the SR in comparison to the LR, in which later maturing varieties with higher yield potential are planted (MOA\&RD, 2001). Productivity did not differ between the two seasons on conversions over 35 years, suggesting that grain yield on these farms was controlled primarily by nutrient availability rather than climate.

Control grain yields can be used as a proxy for ISF, the potential productivity when no fertilizers are added (Wopereis et al., 2006). ISF can decline upon forest clearance and subsequent transition to agriculture because $\mathrm{SOM}$, a main source of plant nutrients, is actively mineralized as a consequence of continuous disturbance of the soil aggregates with cultivation (Collins et al., 2000; Solomon et al., 2007) and a high proportion of plant nutrients lost or removed from the system with annual harvest (Zingore et al., 2005) and through runoff and leaching (Bertol et al., 2007). Studies indicate that the rate of loss of SOM slows with time as a new SOM equili- 
brium is reached that depends on tillage practices (Pikul et al., 2007; Solomon et al., 2007) and the amount of organic matter returned to the soil as crop biomass or animal manures (Kirchmann et al., 2004; Lejon et al., 2007).

In this study, the decline in ISF with increasing time under cultivation corresponded with a decrease in the surface $0.10 \mathrm{~m}$ of soil of preseason soil mineral nitrogen, plant-available $\mathrm{P}\left(\mathrm{P}_{\mathrm{A}}\right)$ and organic $\mathrm{P}\left(\mathrm{P}_{\mathrm{o}}\right)$ (Table 2). In a study of the same chronosequences, Solomon et al. (2007) found that organic carbon in the surface $0.10 \mathrm{~m}$ of soil decreased $84 \%$ and $86 \%$ from primary forest values of 95 and $119 \mathrm{~g} \mathrm{C} \mathrm{kg}^{-1}$ soil for the Nandi and Kakamega sites, respectively, in soils under cultivation for $>40$ years. Total organic $\mathrm{N}$ decreased similarly, from initial values of 9.5 and $10.8 \mathrm{~g} \mathrm{~N} \mathrm{~kg}^{-1}$ soil for the Nandi and Kakamega sites, respectively (Solomon et al., 2007). Soil pH and effective cation exchange capacity also decreased with time under cultivation (Kinyangi, 2008).

In our study, grain yield decline slowed and appeared to be approaching a steady state after 50-100 years of continuous cultivation, though continued low rate of decline in productivity might extend beyond 100 years. The decrease to $24 \%$ of the original ISF in the LR is in the same range of decreases in soil C to approximately $20 \%$ of initial values following long-term cultivation reported by Solomon et al. (2007) for these chronosequences. However, the rate of yield loss was not as great as the rate of carbon loss [Fig. 2 and Solomon et al., 2007 (Fig. 1)], with most of the soil carbon loss occurring within the first 20 years of cultivation. The rates of soil $\mathrm{C}$ decline reported for temperate ecosystems (Davidson \& Ackerman, 1993) and for tropical range land (Solomon et al., 2000; Dieckow et al., 2005) are less than those reported by Solomon et al. (2007) for our sites. The relatively high mean annual temperature and rainfall of the study areas and semiannual perturbation of the soil during cultivation may accelerate the decomposition of SOM in these soils relative to tropical range land and temperate ecosystems.

The grain yields obtained without fertilizer in this study on the old conversions in either the LR or SR (1.6 and $0.98 \mathrm{Mgha}^{-1}$ ) were somewhat $>1 \mathrm{Mgha}^{-1}$ annual (two seasons) grain yield reported for farmers' fields in western Kenya (ICRAF, 1998). The higher yields obtained in this study are probably due to the use of certified maize seed and other recommended crop management practices such as proper plant spacing and pest and disease control, lack of which presumably contributes to low grain yield in most farms in this region (MOA\&RD, 2001).

\section{Effect of applied $N$ and $P$ fertilizers on land productivity recovery}

Before application of $\mathrm{N}$ and $\mathrm{P}$ fertilizers, soil-available $\mathrm{P}$ and mineral $\mathrm{N}$ of these sites decreased with time under cultivation (Table 3). We applied a range of rates of $\mathrm{N}$ and $\mathrm{P}$ to chronosequence soils to assess nutrient limitations as a function of time under cultivation. Experimental manipulation with nutrient amendments has been used previously to identify the most limiting nutrient in an ecosystem (Chapin et al., 1986).

The increase in grain yield obtained as a result of application of either $\mathrm{N}$ or $\mathrm{P}$ alone and significant grain yield increase as a result of applying both $\mathrm{P}$ and $\mathrm{N}$ (Figs 4 and 5) indicate that $\mathrm{N}$ and $\mathrm{P}$ were both limiting in these systems. Jama et al. (1997) and Sanchez et al. (1997) also reported greater responses when applying both $\mathrm{N}$ and $\mathrm{P}$ fertilizers in western Kenya on sites that we would classify as old.

Our results clearly indicate that in the LR season, N and $\mathrm{P}$ productivity response, as well as apparent fertilizer recovery efficiencies for both $\mathrm{N}$ and $\mathrm{P}$, are significantly affected by the age of conversion. Grain yield responses to $\mathrm{N}$ and $\mathrm{P}$ additions differed among the conversions because of the differences in ISF. The tendency of increasing grain yield with increasing $\mathrm{N}$ and $\mathrm{P}$ application on all conversions suggests that even at the highest levels of $\mathrm{N}$ and $\mathrm{P}$ applied in this study $\left(120 \mathrm{~kg} \mathrm{Nha}^{-1}\right.$ and $\left.100 \mathrm{~kg} \mathrm{Pha}^{-1}\right), \mathrm{N}$ and P were still limiting maize productivity. It is likely that there would have been positive response to $\mathrm{N}$ rates as high as $200 \mathrm{~kg} \mathrm{~N} \mathrm{ha}^{-1}$ with adequate $\mathrm{P}$ on the older conversions. The higher grain yield response to $100 \mathrm{~kg} \mathrm{Pha}^{-1}$ compared with $25 \mathrm{~kg} \mathrm{Pha}^{-1}$ suggests that there may have been the potential for further response to higher levels of applied $\mathrm{P}$. These findings imply that the recommendation of $25 \mathrm{kgP}$ and $60 \mathrm{~kg} \mathrm{Nha}^{-1}$ for the region is low from the perspective of maximizing potential grain yield, especially on the old and medium conversions.

Our results showed that ANR decreased with increasing $\mathrm{N}$ rate. This pattern has been found in other studies (Pastor \& Bridgham, 1999; Yuan et al., 2006). The basic principle of apparent nutrient recovery efficiency theory is that plants on $\mathrm{N}$-poor soils are less productive, but more efficient in their use of $\mathrm{N}$ than plants on $\mathrm{N}$-rich soils (Silla \& Escudero, 2004). ANR generally increases as soil $\mathrm{N}$ availability declines (Yuan et al., 2006). The low nitrogen levels in the old and medium conversions partly explain the relatively high ANR for the old and medium conversions attained in this study. The ANR was lower in the young conversions because soil mineral $\mathrm{N}$ was higher (Table 3 ).

The grain yield responses to applied $\mathrm{P}$ were more pronounced on the old and medium conversions with the young conversion showing only a small response. This finding suggests that $\mathrm{P}$ cycling was significantly affected by management following the conversion of tropical forest to permanent agriculture (Townsend 
et al., 2007). The responses in grain yield to the applied treatments were a reflection of the soils' ability to retain and supply available $\mathrm{P}$ from both applied and indigenous sources. In the young conversions, only about $100 \mathrm{mg} \mathrm{P} \mathrm{kg}^{-1}$ soil was estimated to be needed to maintain a critical value of $0.2 \mathrm{mg} \mathrm{PL}^{-1}$ in the soil solution (Kamprath \& Watson, 1980), whereas 185 and $250 \mathrm{mg} \mathrm{P} \mathrm{kg}^{-1}$ soil were required to maintain this critical $\mathrm{P}$ value in medium and old conversion soils, respectively. The resin $\mathrm{P}_{\mathrm{i}}+\mathrm{NaHCO}_{3} \mathrm{P}$ fractions, which are generally equated with the readily available and loosely adsorbed P (Tiessen \& Moir, 1993) were significantly higher in the young conversion. Consequently, young conversion soil was likely able to supply more plantavailable $\mathrm{P}$ than the medium and old conversion soil, which explains the lower rate of grain yield increase in response to added $\mathrm{P}$ and the lower APR in the young conversions compared with the medium and old conversions. The $\mathrm{P}$ bonding energies for the medium and old conversions were similar, which may explain why the apparent $\mathrm{P}$ recovery efficiencies of these conversions were also similar.

Our results suggest that using $\mathrm{N}$ and $\mathrm{P}$ together or $\mathrm{P}$ fertilizer alone can be cost-effective options for increasing land productivity. Despite giving substantially higher grain yield than $25 \mathrm{~kg} \mathrm{Pha}^{-1}, 120 \mathrm{~kg} \mathrm{~N}^{-1}$ had lower BCR and negative or low net benefits due to the high cost of nitrogen fertilizer and consequently would not be attractive to farmers. Jama et al. (1997) reported grain yield increases and positive economic returns from additions of $10 \mathrm{~kg} \mathrm{Pha}^{-1}$ from triple superphosphate fertilizer in western Kenya, and our results indicated positive economic returns and positive benefit cost from applying $25 \mathrm{~kg} \mathrm{Pha}^{-1}$ on medium and old conversions. $\mathrm{N}$ and $\mathrm{P}$ when applied together resulted in higher BCRs and the highest net benefits on all conversions, suggesting that soil fertility improvement strategies should strive to encompass both nutrients. Despite BCRs $>1$ and positive net benefits of $\mathrm{P}$ and $\mathrm{N}$ and $\mathrm{P}$ fertilizer application, high fertilizer rates may not be affordable or may be too risky for many small farmers, and hence efforts to overcome fertility depletion in these systems are likely hampered by the high cost of fertilizer (Sanchez, 2002) relative to the average income of farmers in this region, which for 2003 was reported as 23 Kenya shillings per day (Barrett et al., 2006).

\section{Implication for the future of the tropical highland agroecosystems}

Our study clearly demonstrates the impact of land use on soil productivity decline following conversion of tropical highland forest to agriculture. Land cultivation led to an exponential loss of ISF, associated with a significant loss of soil $\mathrm{N}$ and P. Maize productivity declined exponentially, with 100 -year-old conversions having only $24 \%$ of grain yield of newly converted land. The synergistic effects of $\mathrm{N}$ and $\mathrm{P}$ fertilizer were clearly demonstrated, indicating that there is limited benefit in terms of grain yield increase in the application of either nutrient alone. Furthermore, our study provides evidence that ISF and the cost of fertilizer should be considered when establishing soil nutrient recovery programs. The yield potential for the combined LR and SR seasons in the western highlands of Kenya may be as high as $12 \mathrm{Mgha}^{-1}$. To achieve these yield potentials on old conversions may require fertilizer application rates at least initially as high as $120 \mathrm{~kg} \mathrm{Nha}^{-1}$ and $100 \mathrm{~kg} \mathrm{Pha}^{-1}$ during the LR season and $90 \mathrm{~kg} \mathrm{Nha}^{-1}$ and $25 \mathrm{~kg} \mathrm{Pha}^{-1}$ during the SR season. Current recommended fertilizer application rates for this region are not likely to increase maize yield $>1 \mathrm{Mg} \mathrm{ha}^{-1}$ seasonally. Sanchez (2006) reported that with modest fertilizer use, improved seed and other agronomic practices, grain yield in smallholder agroecosystems in western Kenya increased from 1.5 to $4.5 \mathrm{Mg} \mathrm{ha}^{-1} \mathrm{yr}^{-1}$. On the old conversions, receiving a range of fertilizer additions, we report average grain yields in the LR increasing from 1.8 to $6.6 \mathrm{Mgha}^{-1}$ with the possibility of yields as high as $7 \mathrm{Mgha}^{-1}$. Sufficient fertilizer inputs, along with good crop management practices, can substantially restore the productivity of these soils within a single growing season.

The results of this study have important implications for the restoration of soil fertility in the region and reduction of forest conversion to agriculture. The results reported here support the need to understand the degree of soil degradation to develop useful fertilizer recommendations and, more broadly, to design programs geared towards alleviating soil degradation in tropical ecosystems of developing economies.

\section{Acknowledgements}

This work was supported by NSF Coupled Natural and Human Systems Program of the Bio-complexity Initiative, BCS-0215890 grant through the Cornell International Institute of Food, Agriculture and Development, and the Department of Earth and Atmospheric Sciences, Cornell University and executed in partnership with the World Agroforestry Centre. We thank field technicians at Maseno; Wilson Okila, Joseph Njeri, Lawerence Lanogwa and John Recha; and Kenyan ministry of Agriculture, South Nandi District staff; Mr Lord Mise and $\mathrm{Mr}$ Kima, and farmers representative; Charles Moshi (Tiriki Divison, Kenya) for the invaluable help in the field. We thank the Kenya Forestry Research Institute for logistical support in the field. Any opinions, findings and conclusions or recommendations expressed in this material are those of the authors and do not necessarily reflect the views of the National Science Foundation. 


\section{References}

Anderson J, Ingram J (1993) Tropical Soil Biology and Fertility. A Handbook of Methods. CABI, UK.

Barbier EB (2007) Frontiers and sustainable economic development. Environmental \& Resource Economics, 37, 271-295.

Barrett CB, Marenya PP, McPeak J et al. (2006) Welfare dynamics in rural Kenya and Madagascar. Journal of Development Studies, 42, 248-277.

Bertol I, Engel FL, Mafra AL, Bertol OJ, Ritter SR (2007) Phosphorus, potassium and organic carbon concentrations in runoff water and sediments under different soil tillage systems during soybean growth. Soil \& Tillage Research, 94, 142-150.

Bowman RA (1989) A sequential extraction procedure with concentrated sulfuric-acid and dilute base for soil organic phosphorus. Soil Science Society of America Journal, 53, 362-366.

Boyer EW, Howarth RH (eds) (2002) The Nitrogen Cycles at Regional to Global Scales. Kluwer Academic Publishers, New York, NY, USA.

Buresh RJ, Smithson PC, Hellums DT (1997) Building soil phosphorus capital in Africa. In: Replenishing Soil Fertility in Africa (eds Buresh RJ, Sanchez PA), pp. 111-149. SSSA and ASA, Madison, WI, USA.

Chapin FS, Vitousek PM, Vancleve K (1986) The nature of nutrient limitation in plant-communities. American Naturalist, 127, 48-58.

Collins HP, Elliott ET, Paustian K et al. (2000) Soil carbon pools and fluxes in long-term corn belt agroecosystems. Soil Biology $\mathcal{E}$ Biochemistry, 32, 157-168.

Davidson EA, Ackerman IL (1993) Changes in soil carbon inventories following cultivation of previously untilled soils. Biogeochemistry, 20, 161-193.

Dieckow J, Mielniczuk J, Knicker H, Bayer C, Dick DP, KogelKnabner I (2005) Organic N forms of a subtropical Acrisol under no-till cropping systems as assessed by acid hydrolysis and solid-state NMR spectroscopy. Biology and Fertility of Soils, 42, 153-158.

Donovan G, Casey F (1998) Soil Fertility Management in SubSaharan Africa. World Bank Technical Paper No. 408. World Bank, Washington, DC.

Dorich RA, Nelson DW (1984) Evaluation of manual cadmium reduction methods for determination of nitrate in potassium chloride extracts of soils. Soil Science Society of America Journal, $48,72-75$.

FAO (2003) World Agriculture: Towards 2015/2030, an FAO Perspective. Earthscan Publications Ltd, London, England.

FAO (2005) Global Forest Resources Assessment 2005: 15 key findings. Food and Agricultural Organization of the United Nations, Rome, Italy, www.fao.org/forestry

Fox RL, Kamprath EJ (1970) Phosphate sorption isotherms for evaluating the phosphorus requirements of soils. Soil Science Society of America Proceedings, 35, 902-907.

Friesen DK, Rao IM, Thomas RJ, Oberson A, Sanz JI (1997) Phosphorus acquisition and cycling in crop and pasture systems in low fertility tropical soils. Plant and Soil, 196, 289-294.

Haileslassie A, Priess JA, Veldkamp E, Lesschen JP (2006) Smallholders' soil fertility management in the Central Highlands of Ethiopia: implications for nutrient stocks, balances and sustainability of agroecosystems. Nutrient Cycling in Agroecosystems, 75, 135-146.

Hedley MJ, Stewart JWB, Chauhan BS (1982) Changes in inorganic and organic soil-phosphorus fractions induced by cultivation practices and by laboratory incubations. Soil Science Society of America Journal, 46, 970-976.

ICRAF (1998) International Centre for Research in Agroforestry Annual Report for 1997. ICRAF, Nairobi, Kenya.

Jaetzold R, Schmidt H (1982) Farm Management Handbook of Kenya. Natural Conditions and Farm Management Information. Part A. Western Kenya (Nyanza and Western Provinces). Kenya Ministry of Agriculture and German Government, Nairobi, Kenya.

Jama B, Swinkels RA, Buresh RJ (1997) Agronomic and economic evaluation of organic and inorganic sources of phosphorus in western Kenya. Agronomy Journal, 89, 597-604.

Kamprath EJ, Watson ME (1980) Conventional soil and tissue tests for assessing the phosphorus status of soils. In: The Role of Phosphorus in Agriculture (eds Khasawneh FE, Sample EC, Kamprath EJ), pp. 433-469. ASA, Madison, WI, USA.

Kinyangi J (2008) Soil degradation, thresholds and dynamics of long-term cultivation: from landscape biogeochemistry to nanoscale biogeocomplexity. PhD dissertation, Cornell University, Ithaca, NY, USA, 161 pp.

Kirchmann H, Haberhauer G, Kandeler E, Sessitsch A, Gerzabek MH (2004) Effects of level and quality of organic matter input on carbon storage and biological activity in soil: synthesis of a long-term experiment. Global Biogeochemical Cycles, 18, 38-46.

Lal R (2007) Anthropogenic influences on world soils and implications to global food security. Advances in Agronomy, 93, 69-93.

Lejon DPH, Sebastia J, Lamy I, Chaussod R, Ranjard L (2007) Relationships between soil organic status and microbial community density and genetic structure in two agricultural soils submitted to various types of organic management. Microbial Ecology, 53, 650-663.

Lung T, Schaab G (2004) Change-detection in Western Kenya: The documentation of fragmentation and disturbance for Kakamega forest and associated forest areas by means of remotely-sensed imagery. Proceedings of the ISPRS XXth Congress, Istanbul, Turkey, 12-23 July 2004.

MOA\&RD (2001) Ministry of Agriculture and Rural Development Western Kenya Province 2000 Annual Work Programme, Government of Kenya. Ministry of Agriculture and Rural Development, Kakamega, Kenya.

Murphy J, Riley JP (1962) A modified single solution method for the determination of phosphate in natural waters. Analytica Chimica Acta, 27, 31-36.

Mutuo P, Okoth H, Makomere C et al. (2006) Annual Report for Sauri, Kenya Millennium Research Village July 2005 to June 2006. The Earth Institute at Columbia University, NY, USA.

Ngoze S (2008) Soil nutrient depletion and repletion in a tropical agroecosystem. PhD dissertation, Cornell University, Ithaca, NY, USA, 123 pp.

Nziguheba G, Palm CA, Buresh RJ, Smithson PC (1998) Soil phosphorus fractions and adsorption as affected by organic and inorganic sources. Plant and Soil, 198, 159-168.

Oliva SR, Raitio H, Mingorance MD (2003) Comparison of two wet digestion procedures for multi-element analysis of plant samples. Communications in Soil Science and Plant Analysis, 34, 2913-2923. 
Pastor J, Bridgham SD (1999) Nutrient efficiency along nutrient availability gradients. Oecologia, 118, 50-58.

Pikul JL, Osborne S, Ellsbury M, Riedell W (2007) Particulate organic matter and water-stable aggregation of soil under contras-

ting management. Soil Science Society of America Journal, 71, 766-776.

Pimm SL, Ayres M, Balmford A et al. (2001) Environment - can we defy nature's end? Science, 293, 2207-2208.

Sanchez PA (2002) Ecology - soil fertility and hunger in Africa. Science, 295, 2019-2020.

Sanchez PA (2006) Experts at Africa Summit highlight challenges and promise of increasing farm yield to end hunger: Editors note. Proceedings of the Africa Fertilizer Summit, Abuja, Nigeria, 9-13 June 2006.

Sanchez PA, Shepherd KD, Soule MJ et al. (1997) Soil fertility replenishment in Africa: an investment in natural resource capital. In: Replenishing Soil Fertility in Africa (eds Buresh RJ Sanchez PA), pp. 1-46. SSSA and ASA, Madison, WI, USA.

Sanchez PA, Swaminathan MS (2005) Cutting world hunger in half. Science, 307, 357-359.

Silla F, Escudero A (2004) Nitrogen-use efficiency: trade-offs between $\mathrm{N}$ productivity and mean residence time at organ, plant and population levels. Functional Ecology, 18, 511-521.

Smaling EMA, Toure E, De Ridder N, Sanginga N, Breman H (2006) Fertilizer use and the environment in Africa: Friends or foes? Proceedings of the African Fertilizer Summit, Abuja, Nigeria, 9-13 June 2006.

Smith P, Andren O, Karlsson T, Perala P, Regina K, Rounsevell M, van Wesemael B (2005) Carbon sequestration potential in European croplands has been overestimated. Global Change Biology, 11, 2153-2163.

Solomon D, Lehmann J, Kinyangi J et al. (2007) Long-term impacts of anthropogenic perturbations on dynamics and speciation of organic carbon in tropical forest and subtropical grassland ecosystems. Global Change Biology, 13, 511-530.

Solomon D, Lehmann J, Zech W (2000) Land use effects on soil organic matter properties of chromic luvisols in semi-arid northern Tanzania: carbon, nitrogen, lignin and carbohydrates. Agriculture Ecosystems \& Environment, 78, 203-213.

Stevens PR, Walker TW (1970) The chronosequence concept and soil formation. Quarterly Review of Biology, 45, 330-350.

Tiessen H, Moir JO (1993) Characterization of available P by sequential extraction. In: Soil Sampling and Methods of Analysis (ed. Carter MR), pp. 75-86. Lewis Publishers, Boca Raton, FL.

Tittonell P, Shepherd KD, Vanlauwe B, Giller KE (2008) Unravelling the effects of soil and crop management on maize productivity in smallholder agricultural systems of western Kenya - an application of classification and regression tree analysis. Agriculture Ecosystems \& Environment, 123, 137-150.

Townsend AR, Asner GP, Cleveland CC, Lefer ME, Bustamante MMC (2002) Unexpected changes in soil phosphorus dynamics along pasture chronosequences in the humid tropics. Journal of Geophysical Research - Atmospheres, 107, 8067-8076.

Townsend AR, Cleveland CC, Asner GP, Bustamante MMC (2007) Controls over foliar N:P ratios in tropical rain forests. Ecology, $88,107-118$

Wopereis MCS, Tamelokpo A, Ezui K, Gnakpenou D, Fofana B, Breman H (2006) Mineral fertilizer management of maize on farmer fields differing in organic inputs in the West African savanna. Field Crops Research, 96, 355-362.

Yuan ZY, Li LH, Han XG, Chen SP, Wang ZW, Chen QS, Bai WM (2006) Nitrogen response efficiency increased monotonically with decreasing soil resource availability: a case study from semiarid grassland in northern China. Oecologia, 148, 564-572.

Zingore S, Manyame C, Nyamugafata P, Giller KE (2005) Longterm changes in organic matter of woodland soils cleared for arable cropping in Zimbabwe. European Journal of Soil Science, 56, 727-736

Zingore S, Murwira HK, Delve RJ, Giller KE (2007) Soil type, management history and current resource allocation: three dimensions regulating variability in crop productivity on African smallholder farms. Field Crops Research, 101, 296-305. 